\title{
Development of an Integrated Coastal Vulnerability Index for the Ivorian Coast in West Africa
}

\author{
René A. Tano ${ }^{1}$, Angora Aman ${ }^{2 *}$, Elisée Toualy², Yves K. Kouadio², \\ Bouo Bella Djézia François-Xavier ${ }^{1}$, Kwasi Appeaning Addo ${ }^{3}$ \\ ${ }^{1}$ Laboratory of Fundamental and Applied Physics, Nangui Abrogoua University, Abidjan, Cote d'Ivoire \\ ${ }^{2}$ Climate Tropical Team, Laboratory of Atmospheric Physics and Fluid Mechanics, Felix Houphouet Boigny University of Cocody, \\ Abidjan, Cote d'Ivoire \\ ${ }^{3}$ Institute for Environment and Sanitation Studies, University of Ghana, Accra, Ghana \\ Email: *angora.aman@gmail.com
}

How to cite this paper: Tano, R.A., Aman, A., Toualy, E., Kouadio, Y.K., FrançoisXavier, B.B.D. and Addo, K.A. (2018) Development of an Integrated Coastal Vulnerability Index for the Ivorian Coast in West Africa. Journal of Environmental Protection, 9, 1171-1184.

https://doi.org/10.4236/jep.2018.911073

Received: September 2, 2018

Accepted: October 23, 2018

Published: October 26, 2018

Copyright $(9) 2018$ by authors and Scientific Research Publishing Inc. This work is licensed under the Creative Commons Attribution International License (CC BY 4.0).

http://creativecommons.org/licenses/by/4.0/

\begin{abstract}
This study assesses the vulnerable state of the $566-\mathrm{km}$ Ivorian coastal area using the physical (geomorphology, coastal slope, coastal retreat rate, relative sea level rise and wave/Tide energy) and socio-economic (coastal population density, harbor, airport, road, land use and protected area) factors as indicators. This enabled an Integrated Coastal Vulnerability Index to be determined for the Ivorian coastal zone. This Index could be defined as the weighted average of indexes based on physical and socio-economic factors. The study revealed that vulnerability of the western and the eastern coastlines of Cote d'Ivoire are strongly influenced by human activities, while physical forcing affects significantly the vulnerability of the central section. The relative vulnerability of the different sections depends also strongly on the geomorphology, wave energy, coastal population density and land use factors. The west and central sections of the coastline are more resilient than the eastern section when integrating physical and socio-economic factors. The Integrated Coastal Vulnerability Index, based on physical and socio-economic factors, appears to be more appropriate for coastal vulnerability assessment. These results could be useful in the development of adaptation strategies to increase the resilience of this coastal area and then extended for West Africa Coastal Areas Management.
\end{abstract}

\section{Keywords}

Integrated Coastal Vulnerability Index, Ivorian Coast, Socio-Economic Pressure, Physical Forcing 


\section{Introduction}

The coastal zones correspond to the transition area between land and sea. These coastal areas provide vital ecosystem services and help buffer the coastline against severe extreme events.

In West Africa, the coastal zone concentrates about $31 \%$ of the population and the main infrastructures [1]. This coastal area is exposed to a variety of natural and potentially damaging events that increases the vulnerability and risk levels along the entire West African coastline [2]. The low-lying coastal areas of West Africa (as for instance Lagos and Abidjan) are particularly exposed to sea-level rise and the increase in storm intensities and frequencies. In these two cities, more than 3,000,000 of people are exposed to climate change and extreme events impacts [3]. Extreme events have frequently occurred during these last three decades and have often induced a severe coastline retreat and human life and infrastructures losses. Recently, a strong storm eroded more than $12 \mathrm{~m}$ of Ivorian coastline during two days in August 2011 [4]. High tides and heavy precipitation also increase vulnerability in the coastal zone through permanent processes (such as erosion) and rapid but temporary phenomena (such as coastal flooding) [5].

Recent study assessed the vulnerability of the Ivorian coastline based on physical parameters including geomorphology, coastal slope, coastal retreat rate, relative sea level rise and wave/Tide energy [6]. This study revealed that the vulnerability of the Ivorian coastline increases eastward and is controlled by geomorphology and frequent extreme events such as energetic swell waves [4]. In addition, socio-economic activities could increase the vulnerability of this coastal area because changes induced by socio-economic activities occur often much more rapidly than those related to physical factors [7].

The factors derived from socio-economic activities considered in West Africa coasts are: coastal population density, harbor, airport, road, land use and protected area [8] [9]. The use of these factors is justified by the important role in generating incomes for national economy or severity of pressure in the case of the Ivorian coastal zone. The West African countries are vulnerable to sea level rise, particularly where growing cities with high population density are situated in the coastal zone. Most of these countries undergoing rapid population growth, urbanization, coastward migration and associated socio-economic growth, countries are experiencing dramatic coastal change (e.g. [10]). Airport, road and harbor are the major infrastructures that seem more exposed to the impact of extreme events and accelerate sea-level rise due to their proximity from the coastline (e.g., the distance between the coastline and the Abidjan airport not exceed $1.5 \mathrm{~km}[11])$. Moreover, the protection infrastructure of the harbors can contribute to coastline retreat rate [12] [13] by modifying sediment supply Eastward (case of the Ivorian coastal zone) and they are exposed of energetic wave impacts [14]. Land use expresses the reduction of the natural resilience of the coast and the exposure of agriculture, industrial and urbanization activities. Finally, pro- 
tected area provide natural resilience (protection of the coast against coastal erosion, absorb a part of anthropic gas emission [15] [16] [17]) to the coastal zone and good quality habitats for the different living species, making them less vulnerable to extreme climatic conditions. Despite the fact that these parameters are not exhaustive, they seem representative of the socio-economic vulnerability state in West Africa coastal areas [18].

Some authors [7] [8] [19] [20] have proposed methods (Table 1) to quantify the coastal vulnerability index taking into account physical and socio-economic factors. However, the proposed formulas seem limited. The limitation is due to the fact that the Coastal Vulnerability Index derived from physical and socio-economic parameters is balanced with the same coefficient. This supposes that socio-economic and physical variables are uniformly distributed along the coast. This hypothesis is not always true because the parameters derived from socio-economic factors could contribute more to the coastal vulnerability than the physical factors [7]. Then, a new approach of coastal vulnerability index called Integrated Coastal Vulnerability Index (ICVI) is proposed in this study. The innovation here comes from the integration of a proportional coefficient relative to socio-economic and physical factors in the vulnerability index. This Integrated coastal vulnerability index illustrates the degree of exposure of coastal areas to the impacts of physical and socio-economic factors.

Despite of the impact of these factors on the coastal environment, no serious

Table 1. Summary of coastal vulnerability index combining physical and socio-economic parameters.

\begin{tabular}{|c|c|c|c|}
\hline Indexes & Weighted coefficients & Limitationss & References \\
\hline $\begin{array}{l}\text { CVI }=\frac{(\mathrm{CC}+\mathrm{CF}+\mathrm{SE})}{3} \\
\text { CC: Coastal characteristic; CF: Coastal } \\
\text { forcing; SE: socio-economic. }\end{array}$ & $\alpha=\beta=\gamma=\frac{1}{3}$ & \multirow{4}{*}{$\begin{array}{l}\text { All factors } \\
\text { (Physical and } \\
\text { Socio-economic) } \\
\text { are uniformly } \\
\text { distributed }\end{array}$} & {$[8]$} \\
\hline $\begin{array}{l}\text { TVI }=\frac{\text { NVI }+ \text { SEVI }}{2} \\
\text { TVI: Total Vulnerability Index; NVI; Natural } \\
\text { Vulnerability Index; SEVI: Socioeconomic } \\
\text { Vulnerability Index. }\end{array}$ & $\alpha=\beta=\frac{1}{2}$ & & [7] \\
\hline $\begin{array}{l}\mathrm{CVI}_{\text {impact }}=\frac{0.5 \times \sum_{1}^{n} \mathrm{PP}_{n}+0.5 \times \sum_{1}^{m} \mathrm{HP}_{m}}{\mathrm{CVI}_{\text {least vulnerable }}} \\
\text { PP: Physical Parameters; HP: Human } \\
\text { influence parameters; } n \text { : number of Physical } \\
\text { Parameter; } m \text { : number of Human influence } \\
\text { parameters. }\end{array}$ & $\alpha=\beta=\frac{1}{2 \mathrm{CVI}_{\text {least vulnerable }}}$ & & [19] \\
\hline $\begin{array}{l}\quad \text { CCVI }=\frac{\frac{\sum \text { PCVI }}{N}+\frac{\sum \text { FCVI }}{N}}{2} \\
\text { PCVI: Physical Coastal Vulnerability Index; } \\
\text { FCVI: Fiscal Coastal Vulnerability Index; } N \text { : } \\
\text { Number of parameters. }\end{array}$ & $\alpha=\beta=\frac{1}{2 N}$ & & [20] \\
\hline
\end{tabular}


studies were undertaken combining physical and socio-economic factors to evaluate the vulnerability of the Ivorian coastal area. This is the first time that a quantitative assessment of a coastal vulnerability is performed along the Ivorian coastline combining physical and socio-economic factors.

The aim of this paper is to assess the vulnerability index of the Ivorian coastal zone by combining both physical and socio-economic factors. The index derived from socio-economic and physical factors computation provides a quantification of their respective weight in the coastal vulnerability. The results will facilitate selecting the appropriate adaptation method for the increasing of the resilience of this coastal area. The materials and methods are presented in the first section. The second section focuses on the results which include the quantification and spatial variability of the Ivorian coastline vulnerability indexes due to socioeconomic factors and that related to both physical and socio-economic factors. This part includes also the identification of the parameters which could drive changes in the coastal environment in each coastal section. A summary of the main results and challenges are given in the last part.

\section{Materials and Methods}

\subsection{Materials}

In order to quantify the Ivorian coastal vulnerability index to socio-economic pressure and its combination with physical parameters, relevant data were gathered from various sources. The coastal vulnerability index (CVI) data (Figure 1) was taken from [6]. The socio-economic datasets were obtained from government agencies such as Centre National de Télédétection et d'Information Géographique (CNTIG) and Institut National de la Statistique (INS) as well as journal articles. The distribution of socio-economic data along the coast is provided by CNTIG and [21]. The spatial distribution of the dataset is presented in Figure 2. The main infrastructures such as airport, harbor, military base and oil and gas activities are located in Section 3 (Abidjan, Cape Three Points). These six parameters were then computed to assess the Ivorian socio-economic coastal vulnerability index (SVI).

\subsection{Methods}

\subsubsection{Coastal Vulnerability Index}

The coastal vulnerability index firstly consists of classifying qualitative (geomorphology, coastal slope) and quantitative factors (shoreline, sea-level rise, mean wave and mean tide height) as new no-dimensional "risk" variables. Each risk variable ranges between 1 and 5 and illustrates its degree of vulnerability. Then, the CVI was calculated for each coastal zone through the following equation:

$$
\mathrm{CVI}=\left(\frac{1}{N} \prod_{i=1}^{N} x_{i}\right)^{\frac{1}{2}}
$$




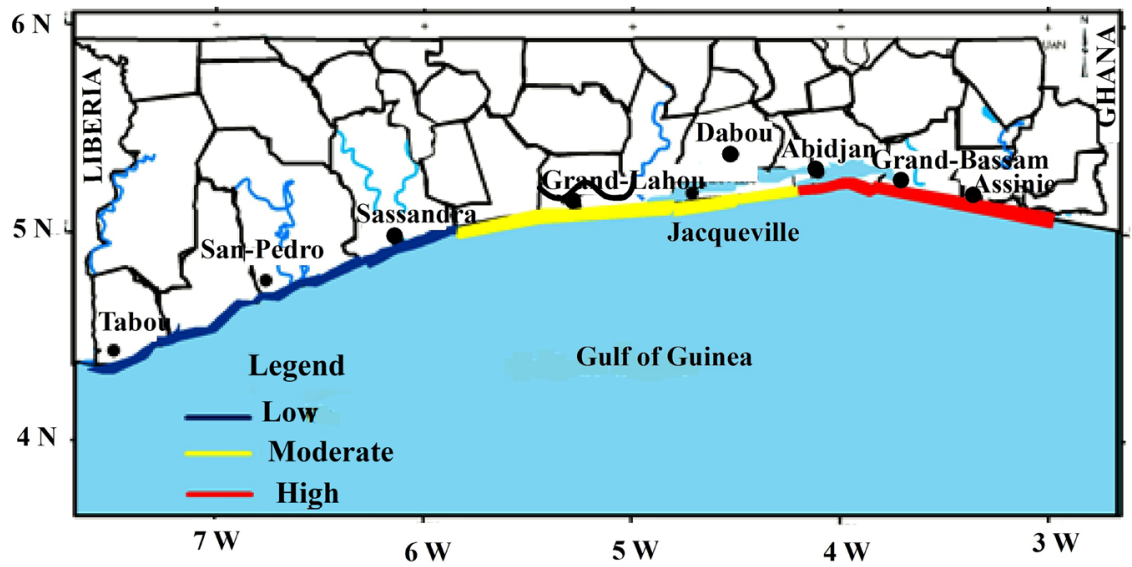

Figure 1. Spatial variability of the coastal vulnerability index (CVI) based on physical parameters along the Ivorian coastline.

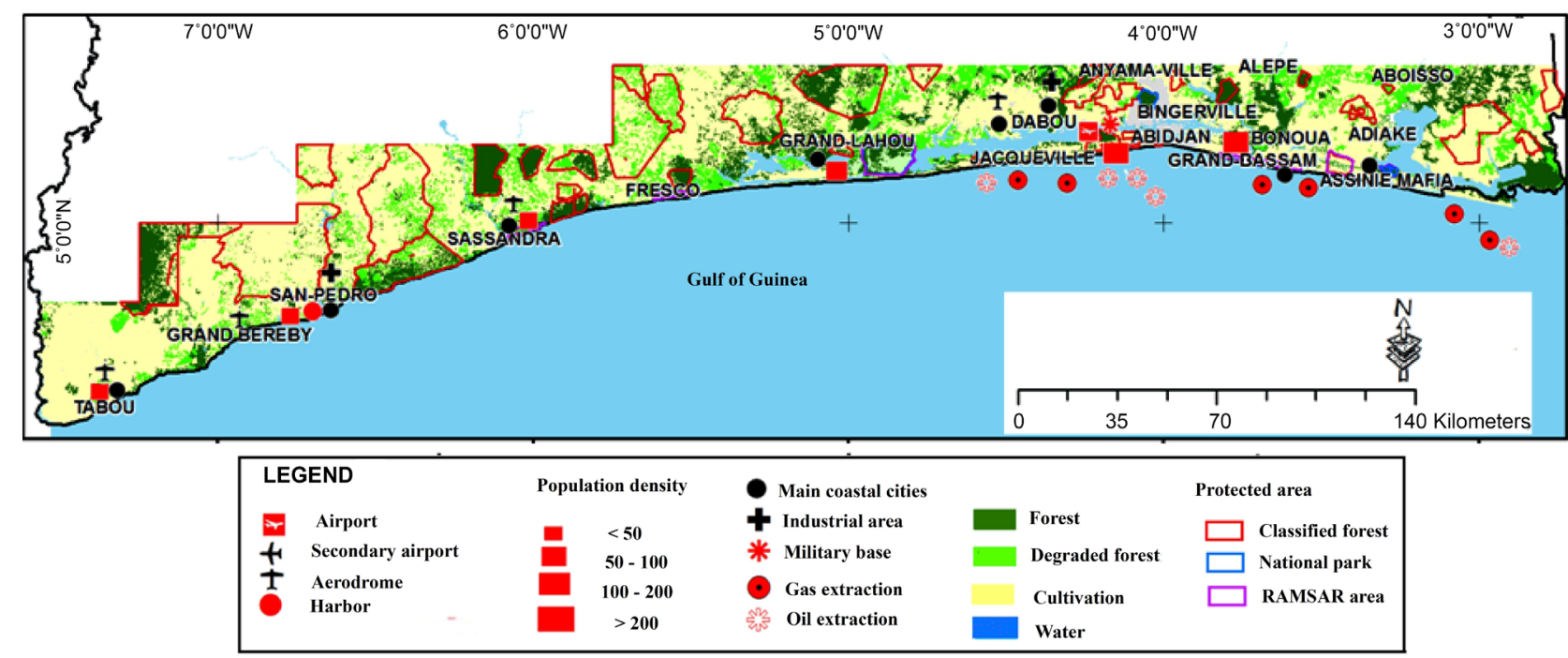

Figure 2. Spatial distribution of socio-economic factors along the Ivoirian coast (adapted from CNTIG).

$N=6$ is the number of physical parameters; $x_{1}$ is associated to the geomorphology, $x_{2}$ is the coastal slope and $x_{3}$ represents the shoreline change rate. The relative sea-level rise, the mean tidal height and the mean significant wave height correspond respectively to $x_{4}, x_{5}$, and $x_{6}$.

In this study, the CVI data are only available for the three sections because of the lack of high resolution coastal retreat rate and tidal gauge datasets.

\subsubsection{Socio-Economic Vulnerability Index (SVI)}

In order to quantify the SVI for each main city of each coastal section, the qualitative (airport, road, harbor, land use and protected area) and quantitative (coastal population density) factors have been classified as new variables ranged between 1 and 5 which could illustrate the degree of vulnerability (Table 2), in accordance with [8] [9]. The annual SVI is computed for each city according to the following equation: 
Table 2. Ranking of relative risk factors relative to population density, airport, road, harbor, land use and protected area. Empty box correspond to no risk factor.

\begin{tabular}{cccccc}
\hline $\begin{array}{c}\text { Degree of } \\
\text { vulnerability }\end{array}$ & Very low & Low & Moderate & High & Very high \\
\hline $\begin{array}{c}\text { Variable } \\
\begin{array}{c}\text { Population density } \\
\left(\mathrm{hbt} / \mathrm{km}^{2}\right)\end{array}\end{array}$ & 1 & 2 & 3 & 4 & 5 \\
Airport & Absent & Aerodrome & $\begin{array}{c}\text { Regional } \\
\text { airport }\end{array}$ & A'Class & International airport \\
Road & Absent & Absent & Cleared & Natural & Motorway \\
Harbor & Forest & vegetation & grasslands & $\begin{array}{c}\text { Agriculture } \\
\text { Dual carriageway } \\
\text { Land use }\end{array}$ & $\begin{array}{c}\text { Prban and industrial } \\
\text { Infrastructure } \\
\text { Absent }\end{array}$ \\
\hline
\end{tabular}

$$
\mathrm{SVI}=\left(\frac{1}{N} \prod_{i=1}^{N} v_{i}\right)^{\frac{1}{2}}
$$

where $N=6$ is the number of socio-economic parameters; $V_{1}, V_{2}, V_{3}, V_{4}, V_{5}$ and $v_{6}$ represent population density, airport, road, harbor Land use and protected area respectively.

The assessment of coastal vulnerability based on physical and socio-economic factors require also the identification of the different parameters which affect mostly the vulnerability of each coastal section. It represents key information that will help to elaborate the appropriate adaptation measures for the vulnerability reduction risk relative to each coastal section. The mean SVI and CVI were computed for each coastal section defined previously. The ratio $\left(\mathrm{SVI}_{\text {norm }} / \mathrm{CVI}_{\text {norm }}\right)$ of the normalized SVI ( $\left.\mathrm{SVI}_{\text {norm }}\right)$ and the corresponding normalized CVI $\left(\mathrm{CVI}_{\text {norm }}\right)$ enabled the identification of the main factor (physical or socio-economic) which affects significantly the vulnerability of the corresponding section. If the ratio is lower than 1 , the vulnerability of the associated section depends strongly on the physical factors. If this ratio is equal to 1 , then the coastal section is equitably affected by both physical and socio-economic factors. Finally, if the ratio is higher than 1 , then, the influence of the socio-economic factors represents the main vulnerability factors.

\subsubsection{Integrated Coastal Vulnerability Index (ICVI)}

The integrated coastal vulnerability index illustrates the degree of exposure of coastal areas to the impacts of physical and socio-economic factors. The new approach of the coastal vulnerability index called integrated coastal vulnerability index (ICVI) computed in this study can be expressed by the Equation (3) as follows:

$$
\mathrm{ICVI}=\frac{\alpha \times C V I+\beta \times \mathrm{SVI}}{\alpha+\beta}
$$


where $\alpha$ and $\beta$ represent the weighting coefficients relative to physical and socio-economic factors respectively in Equation (3).

Equation (3) can be rewritten as follow:

$$
\mathrm{ICVI}=\frac{\mathrm{CVI}+\frac{\beta}{\alpha} \times \mathrm{SVI}}{1+\frac{\beta}{\alpha}}
$$

According to Equation (4), the relative importance of each factor category depends of the coefficient $\frac{\beta}{\alpha}$, so, if:

1) $\frac{\beta}{\alpha}<1 \rightarrow \alpha>\beta$; the vulnerability is mainly controlled by the physical factors;

2) $\frac{\beta}{\alpha}>1 \rightarrow \alpha<\beta$; the socio-economic factors dominates the vulnerability of the coastal zone;

3) $\frac{\beta}{\alpha}=1 \rightarrow \alpha=\beta$; the vulnerability of the associated coastal zone depends on both socio-economic and physical factors.

In the previous sub-section, it was noted that the ratio of the SVI normalized and CVI normalized enabled identifying the type of factor that governs the vulnerability of a given coastal section. So, one can reasonably write $\frac{\beta}{\alpha}=\frac{\mathrm{SVI}_{\text {norm }}}{\mathrm{CVI}_{\text {norm }}}$, which is called weighting coefficient in the follow. Then, the integrated coastal vulnerability index $\operatorname{ICVI}_{i j}$ of each city $i$ belonging to a coastal section $j$ can be computed by the following formula:

$$
\mathrm{ICVI}_{i j}=\frac{\mathrm{CVI}_{i j}+a_{i j} \times \mathrm{SVI}_{i j}}{1+a_{i j}}
$$

where $\mathrm{CVI}_{i j}$ and $\mathrm{SVI}_{i j}$ represent respectively the physical forcing for the section $i$ and the human pressure for the city $i$ includes in section $j . a_{i j}$ is the ratio of normalized SVI and CVI of the section $j$.

In the previous sub-section, we noted that the ratio of the SVI normalized and CVI normalized enabled the identification of the type of factor that governs the vulnerability of a given coastal section.

Finally, each coastal zone could then be classified as low, moderate, high or very high-risk categories vulnerability based on the quartile ranges of the SVI (resp. ICVI) data [22]. If the SVI (resp. ICVI) is weaker than the $25^{\text {th }}$ percentile, then the associated area falls into a low vulnerability risk. Moderate and high vulnerability represented the SVI (resp. ICVI) between the $25^{\text {th }}$ and $50^{\text {th }}$ percentiles and $50^{\text {th }}$ and $75^{\text {th }}$ percentiles respectively. Very high vulnerability is characterized by SVI (resp. ICVI) greater than the $75^{\text {th }}$ percentile.

\section{Results and Discussion}

This section is composed of three parts. The results of the Ivorian Socio-economic 
Vulnerability Index (SVI) and its spatial variability are presented in the first part. The identification of the main factors (physical or socio-economic) that governs the vulnerability of each section constitutes the second part of this section. The last part focuses on the Ivorian integrated coastal vulnerability index and its spatial variability.

\subsection{Influence of Socio-Economic Factors on Ivorian Coastline}

The impact of human activities on the Ivorian coastal area is quantified by computing the SVI of this area.

The SVI illustrates the degree to which coastal areas are threatened by socio-economic factors. This analysis is undertaken by creating a SVI for each main coastal city. As described in the "Methods" sub-section, socio-economic factors are transformed into new variables, which are summarized in Table 3. According to this table, the degree of vulnerability associated to land use factor is high for most of the cities except Tabou, Grand-Lahou and Jacqueville. The population density decreases westward. Socio-economic factors are therefore low compared to that observed in the eastern coastal zone. Most of the socio-economic factors have a high degree of vulnerability in Abidjan. As for the Abidjan city for instance which is densely populated, the very high presence of industrial, commercial (port and airport) and urban infrastructures justify its very high degree of vulnerability. The construction of these infrastructures and the uncontrolled urbanization are carried out to the detriment of the factors of resilience of the coast (vegetation cover). The area around the Tabou (western coastal side) city has the weaker degree of vulnerability because of the low population density, lack of modern infrastructures and protected areas.

Figure 3 represents the spatial variability of the Socio-economic Vulnerability Index (SVI). This Figure shows that the SVI increases eastward from 0.58 (Tabou) to 22.82 (Abidjan). The 25th (1.54), 50th (4) and 75th (6.17) percentiles of all SVI show that the mean value of the Ivorian coastal zone SVI (5.79) falls within the high-risk category. According to the classification based on percentiles

Table 3. Socio-economic or human pressure vulnerability matrix derived from data in Table 2.

\begin{tabular}{ccccccc}
\hline Coastal city & $\begin{array}{c}\text { Population density } \\
\left(\mathrm{hbts} / \mathrm{km}^{2}\right)\end{array}$ & Airport & Road & Harbor & Land use & Protected area \\
\hline Tabou & 1 & 2 & 1 & 1 & 1 & 1 \\
San-Pedro & 1 & 3 & 3 & 5 & 5 & 1 \\
Sassandra & 1 & 2 & 3 & 1 & 4 & 5 \\
Grand-Lahou & 1 & 1 & 3 & 1 & 1 & 1 \\
Jacqueville & 2 & 1 & 1 & 1 & 2 & 5 \\
Dabou & 2 & 2 & 3 & 1 & 4 & 5 \\
Abidjan & 5 & 5 & 5 & 5 & 5 & 1 \\
Grand-Bassam & 3 & 1 & 5 & 1 & 5 & 1 \\
\hline
\end{tabular}




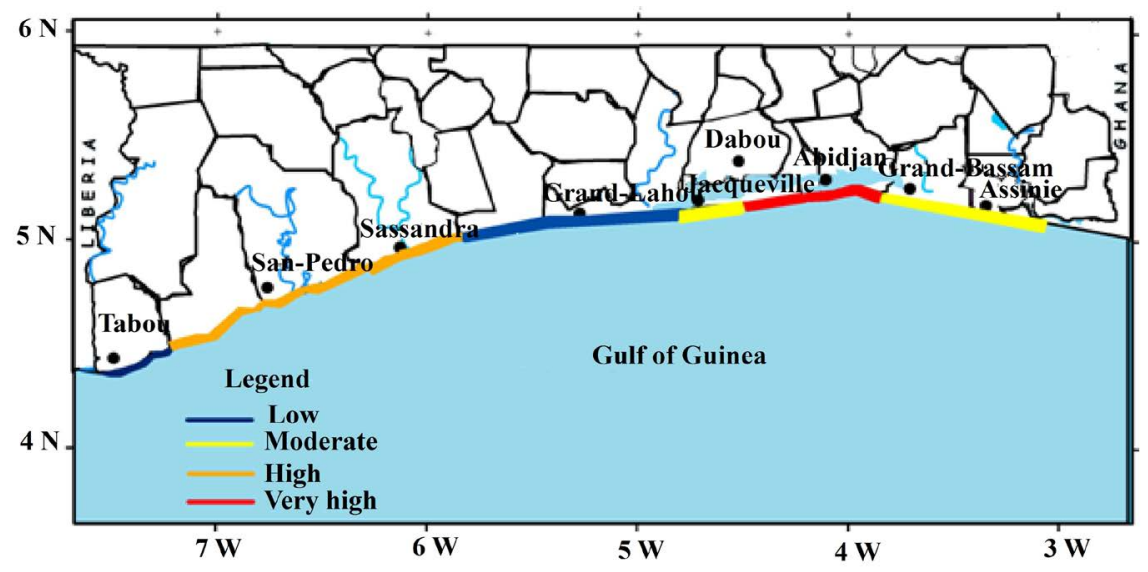

Figure 3. Spatial variability of socio-economic index (SVI) along the Ivorian coastline.

computation, Tabou (0.58) and Grand-Lahou (0.71) cities are characterized by low-risk categories. This can be explained by the fact that these cities have very few infrastructures likely to be negatively affected by human activities. These two sites have only one aerodrome and a dubbed road called "la côtière". Moreover, the presence of resilience factors such as protected areas (protected forest of Tai, Azagny national park) contributes to safeguard the coastal environment. The vulnerability of this coastal section is mainly influenced by physical factors.

Jacqueville (1.83) and Grand-Bassam (3.54) have moderate degree of vulnerability. Thus, they appear to be a balance between risk factors (socio-economic) and the resilience factor (protected area). The status of world heritage of Grand-Bassam and the presence of protected area such as mangrove forest near this city could explain its moderate vulnerability.

In the western coast, San-Pedro (6.12) and Sassandra (4.47) cities fall into high risk-category. The high degree of vulnerability observed at Sassandra is controlled by the degradation of land use and its low natural resilience (absence of protected area).

Finally, Dabou (6.32) and Abidjan (22.82) cities located in the eastern coastal section have the highest socio-economic vulnerability indexes due mainly to socio-economic factors: these two cities fall in very high risk category. When considering each zone, the cities which shelter important trade infrastructures (harbor and airport activities) or concentrate high density population like San-Pedro and Abidjan seem to be the most vulnerable (Figure 3).

The port cities of San-Pedro and Abidjan have been classified in high and very high risk categories respectively, which mean higher exposure to inundation, erosion and others coastal hazards. This result is confirmed by [23] and [3] who have noted that Abidjan is one of the most vulnerable African cities in term of population and assets exposures. The very high presence of industrial, commercial (port and airport) and urban infrastructures in Abidjan explains its very high degree of vulnerability. The construction of these infrastructures and the uncontrolled urbanization are carried out to the detriment of the factors of resilience of the coast. 
The very high vulnerability of Dabou city is due to the high human concentration and the reduction of the forest area in favor of cash crops such as rubber, palm oil as noted by [24] and the absence of resilience factors such as protected areas and forest cover. The destruction of forest, especially mangrove forests, along the east Ivorian coast [25] reduces its ability to protect the coast against energetic swell wave action.

\subsection{Identification of the Main Factor of Vulnerability Associated to Each Coastal Section}

The identification of the main factor (physical or socio-economic) that governs the vulnerability of each coastal section is important when adaptation measures are considered. The ratio of normalized derived from SVI and CVI values are $1.13,0.41$ and 1.27 for west, center and east sections respectively. The vulnerability of coastal subdivision of west and east sections are dominated by physical and socio-economic factors according to the ratios of their normalized values which are close to 1 . Hence adaptation solutions should focus on both physical and socio-economic factors. The vulnerability of the center section depends mainly on physical factors with regard to weaker value of the ratio. For instance, the city of Grand-Lahou undergoes recurrent inundation and coastline retreated due to strong southern swell and exceptional ocean tide [13]. These risks have induced the relocation of the city to $18 \mathrm{~km}$ inland and resulted in loss of human life, local culture heritage and ecosystem such as mangrove forests. To reduce the impact of these risks on population and ecosystem, the World Bank is financing the WACA (West Africa Coastal Areas) program in order to increase the resilient of population and assets.

\subsection{The Ivorian Integrated Coastal Vulnerability Index}

Figure 4 shows the spatial variability of the Ivorian integrated coastal vulnerability derived from the combination of physical and socio-economic factors. The ICVI for each main city increases eastward from 1.85 (Tabou) to 17.34 (Abidjan). The mean value of ICVI is around 6.57 showing that the Ivorian coastal zone falls within high-risk category. Tabou (1.85) and Sassandra (3.92) located in the western coast are in low-risk category. San-Pedro (4.79) and Grand-Lahou (5.37) are characterized by moderate degree of vulnerability. Jacqueville (5.69) and Grand-Bassam (6.54) fall in high risk-category. Finally, Dabou (6.99) and Abidjan (17.34) represent the most vulnerable coastal cities. This result shows that the coastal cities including Sections 1 and 2 are more resilient than those of the coastal subdivision 3 .

Spatial variability of ICVI values has shown that the western and the center cities localized along the Ivorian coast are more resilient than those of the eastern side. For example, The San-Pedro city which was classified in low risk category when considering only physical factor falls within moderate risk category when socio-economic factors are integrated in the vulnerability index computation. 


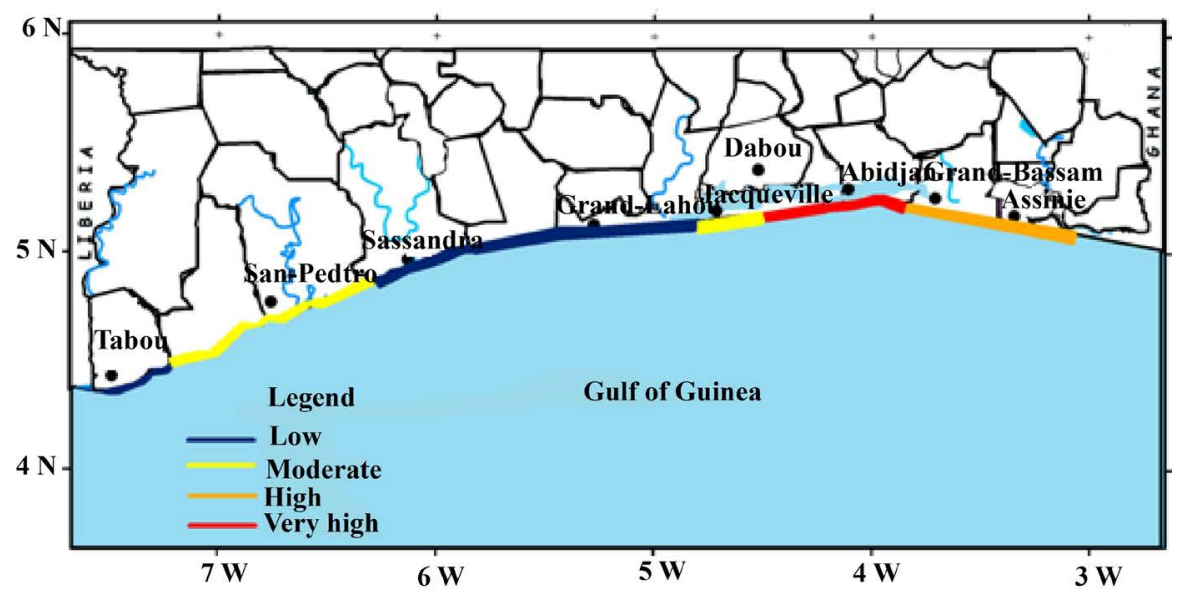

Figure 4. Spatial variability of integrated coastal vulnerability index (ICVI) along the Ivorian coastline.

The high vulnerability observed in the eastern coastal areas is due to the low coastal elevation [6], natural increasing of the coastal population and coastward migration [3]. The Integrated vulnerability indexes for different coastal cities will increase over the years due to rapid population growth and the number of coastal economic activities [24], continuous sea-level rise, increasing of southern wave and extreme coastal events. This increase could be particularly significant in harbor cities such as Abidjan and San-Pedro as in other coastal cities due to natural population growth and coastal migration. The Abidjan city, for instance, appears to be one of the most exposed in terms of population and economic assets in Africa, based on scenarios for physical and socio-economic factors as noted by [23]. The high risk of the eastern section requires urgent measures to protect the coastal environment and its resources. This coastal protection could include relocating near-coastal inhabitants to preserve life and to safeguard coastal infrastructure and ecosystems from the threats of extreme events.

The results of the ICVI are in accordance with the literature of sea-level rise such that low-lying areas are more vulnerable to impacts of climate change and associated factors such as sea-level rise [3] [6] [24] and human pressure as is the case in east of Ivorian coastline. This new index could be improved by including high-quality and high resolution coastal retreat rate, tidal gauge, socio-economic, marine and soil pollution and rainfall data or by weighting the input variables. The ICVI method could be used to evaluate the vulnerability of the entire Gulf of Guinea coastline to climate change and non-climate factors.

This study could particularly contribute significantly to the West Africa Coastal Areas Management Program (WACA) which aims to assist West African countries to sustainably protect their coastal areas and enhance socio-economic resilience to the effects of climate change.

\section{Conclusions}

This article evaluated and estimated the vulnerability of the Cote d'Ivoire coastal 
zone due to both physical and socio-economic factors.

The Coastal vulnerability index (CVI) computed for each zone according to the physical factors shows that the relative vulnerability of the different sections depends strongly on the geomorphology and on the wave energy factors. This vulnerability increases spatially westward taking account of their CVI values.

The socio-economic vulnerability index (SVI) carried out for each coastal section increases eastward. This vulnerability is mostly controlled by coastal population density, the irrational use of land, uncontrolled urbanization and the presence of commercial, industrial and urban infrastructures.

This study showed that the degradation of sections 1 and 3 is mainly due to human pressure. In contrary, the center section of the coast is more exposed to the impacts of physical factors.

A development of an integra ted coastal vulnerability index (ICVI) based on physical and previous socio-economic factors is also carried out in this study. The ICVI appears to be more appropriate for assessing the degree of exposure of a given coastline to the impacts of these factors due to the combining of the CVI and SVI indexes.

The spatial variability of the Ivorian ICVI increased eastward. The western section of the coast appears more resilient than the eastern side, which appears to be the most exposed to various risks. This eastern section deserves special attention from the Ivorian government and the end users.

\section{Acknowledgements}

The authors thank the Centre National de Télédétection et d'Information Géographique (CNTIG) and the Institut National de la Statistique (INS), which provided us with high-quality socio-economic data.

\section{Conflicts of Interest}

The authors declare no conflicts of interest regarding the publication of this paper.

\section{References}

[1] WACA (West Africa Coastal Areas Management Program) (2016) A Partnership for Saving West Africa's Coastal Areas. World Bank Group.

http://pubdocs.worldbank.org/en/622041448394069174/1606426-WACA-Brochure. pdf

[2] Appeaning Addo, K. (2013) Assessing Coastal Vulnerability Index to Climate Change: The Case of Accra-Ghana. In: Conley, D., Masselink, G., Russell, P. and O'Hare, T., Eds., Proceeding from the International Coastal Symposium (ICS) 2013, Journal of Coastal Research, Special Issue No. 65, 1892-1897.

[3] Brown, S., Kebede, A.S. and Nicholls, R.J. (2011) Sea-Level Rise and Impacts in Africa, 2000 to 2100

http://www.joyhecht.net/East\%20Africa\%20Climate\%20Change/Brown\%20et\%20al \%20Sea\%20Level\%20Rise.pdf

[4] Toualy, E., Aman, A., Koffi, P., Marin, F. and Wango, T.E. (2015) Ocean Swell Va- 
riability along the Northern Coast of the Gulf of Guinea. African Journal of Marine Science, 37, 353-361. https://doi.org/10.2989/1814232X.2015.1074940

[5] Tano, R.A., Aman, A., Kouadio, K.Y., Toualy, E., Ali, K.E. and Assamoi, P. (2014) Validation of a Tidal Prediction Model for Ivorian Coastline: Application for Coastal Vulnerability Study. Revue Ivoirienne des Sciences et Technologie, 24, 1-11.

[6] Tano, R.A., Aman, A., Kouadio, K.Y., Toualy, E., Ali, K.E. and Assamoi, P. (2016) Assessment of the Ivorian Coastal Vulnerability. Journal of Coastal Research, 32, 1495-1503. https://doi.org/10.2112/JCOASTRES-D-15-00228.1

[7] Szlafstein, F. and Sterr, H. (2007) A Gis-Based Vulnerability Assessment of Coastal Natural Hazards, State of Para, Brazil. Journal of Coast Conservation, 11, 53-56. https://doi.org/10.1007/s11852-007-0003-6

[8] McLaughlin, S., McKenna, J. and Cooper, J.A.G. (2002) Socio-Economic Data in Coastal Vulnerability Indices: Constraints and Opportunities. In: Cooper, J.A.G. and Jackson, D.W.T., Eds., Proceedings from the International Coastal Symposium (ICS) 2002 (Northern Ireland), Journal of Coastal Research, Special Issue No. 36, 487-497. https://doi.org/10.2112/1551-5036-36.sp1.487

[9] Mahapatra, M., Ramakrishnan, R. and Rajawat, A.S. (2015) Coastal Vulnerability Assessment Using Analytical Hierarchical Process for South Gujarat Coast, India. Natural Hazards, 76, 139-159. https://doi.org/10.1007/s11069-014-1491-y

[10] Boko, M., Niang, I., Nyong, A., Vogel, C., Githeko, A., Medany, M., Osman-Elasha, B., Tabo, R. and Yanda, P. (2007) Africa. In: Parry, M.L., Canziani, O.F., Palutikof, J.P., van der Linden, P.J. and Hanson, C.E., Eds., Climate Change 2007: Impacts, Adaptation and Vulnerability. Contributions of Working Group II to the Fourth Assessment Report of the Intergovernmental Panel on Climate Change, Cambridge University Press, Cambridge, 433-467.

[11] Colin, C., Gallardo, Y., Chuchla, R. and Cissoko. S. (1993) Environnement Climatique et océanographique du plateau continental de Côte d'Ivoire. In Environnement et ressources aquatiques de Côte d'Ivoire. Tome I: le milieu marin, Ed., ORSTOM, Paris, 76-110.

[12] Ibe, A.C. and Quelennec, R.E. (1989) Méthodologie d'Inventaire et de Contrôle de l'Erosion Côtière dans la Région de l'Afrique de l'Ouest et du Centre. Rapports et Etudes mers régionales, Nairobi, PNUE, 107 p.

[13] Wognin, A.V.I., Monde, S., Adopo, K.L., Wango, T.E. and Aka, K. (2012) MorphoSédimentologie du plateau continental Cote d'Ivoire (Golfe de Guinée). Communication Science \& Technologie, 11, 1-14.

[14] Yao, K.S., Abe, J., Bamba, S.B., Konan, K.E. and Aka, K. (2010) Dynamique d'un périmètre littoral portuaire: La côte de San-Pédro, Sud-Ouest de la Côte d'Ivoire. Revue-Paralia.

[15] Burke, L., Kura, Y., Kasem, K., Revenga, C., Spalding, M. and Mcallister, D. (2001) Coastal Ecosystems. World Resource Institute, Washington DC, 93.

[16] Mansourian, S., Belokurov, A. and Stephenson, P.J. (2009) Rôle des aires protégées forestières dans l'adaptation aux changements climatiques. Unasylva, 60, 231-232.

[17] Ellison, J.C. (2015) Vulnerability Assessment of Mangroves to Climate Change and Sea-Level Rise Impacts. Wetlands Ecology and Management, 23, 115-137.

[18] Ibe, A.C. and Awosika, L.F. (1991) Sea Level Rise Impact on African Coastal Zones. In: Omide, S.H. and Juma, C., Eds., A Change in Weather. African Perspectives on Climate Change, African centre for Technology Studies, Nairobi, 105-112.

[19] Özyurt, G. and Ergin, A. (2009) Application of Sea Level Rise Vulnerability Assess- 
ment Model to Selected Coastal Areas of Turkey. Journal of Coastal Research, 56, 248-251.

[20] Kantamaneni, K., Phillips, M. and Thomas, T. (2018) Rhian Jenkins Assessing Coastal vulnerability: Development of a Combined Physical and Economic Index. Ocean and Coastal Management, 158, 164-175.

https://doi.org/10.1016/j.ocecoaman.2018.03.039

[21] INS (Institut National de la Statistique) (2012) Annuaire des statistiques démographiques et sociales. $153 \mathrm{p}$. http://www.ins.ci/n/templates/Pub/annuaire\%20demo.pdf

[22] Thieler, E.R. and Hammar-Klose, E.S. (2000) National Assessment of Coastal Vulnerability to Sea-Level Rise: Preliminary Results for the U.S. Gulf of Mexico Coast. U.S. Geological Survey, Woods Hole, Open-File Report 00-179. https://pubs.usgs.gov/of/2000/of00-179/pages/cvi.html

[23] Nicholls, R.J., Hanson, S., Herweijer, C., Patmore, N., Hallegatte, S., Corfee Morlot, J., Chateau, J. and Muir-Wood, R. (2008) Ranking Port Cities with High Exposure and Vulnerability to Climate Extremes: Exposure Estimates. OECD Environment Working Papers, No. 1, OECD Publishing. https://doi.org/10.1787/011766488208

[24] Nicholls, R.J., Wong, P.P., Burkett, V.R., Codignotto, J.O., Hay, J.E., McLean, R.F., Ragoonaden, S. and Woodroffe, C.D. (2007) Coastal Systems and Low-Lying Areas: Climate Change 2007-Impacts, Adaptation and Vulnerability. In: Parry, M.L., Canziani, O.F., Palutikof, J.P., van der Linden, P.J. and Hanson, C.E., Eds., Contribution of Working Group II to the 4th Assessment Report of the Intergovernmental Panel on Climate Change, Cambridge University Press, Cambridge, 315-356.

[25] FAO (Food and Agriculture Organisation) (2005) Évaluation des ressources forestières mondiales. Étude thématique sur les mangroves, Côte d'Ivoire, Profil National, $11 \mathrm{p}$. http://www.fao.org/forestry/9209-09f178a320d7cc85bd7dc29bbf00bb10.pdf 